\title{
SELF-REVIEW OF PARENTING STYLES: EXPERIENCES IN A GROUP OF SOCIALLY VULNERABLE MOTHERS IN NORTHERN BRAZIL
}

\author{
Rosângela Darwich ${ }^{1}$, \& Ana Letícia Nunes ${ }^{2}$ \\ ${ }^{I}$ Graduate Program in Communication, Languages and Culture; Center for Health and Biological \\ Sciences, Universidade da Amazônia (Brazil) \\ ${ }^{2}$ Center for Health and Biological Sciences, Universidade da Amazônia (Brazil)
}

\begin{abstract}
This study presents a proposal for a group intervention with mothers of children from six to twelve years old in a situation of social vulnerability. We aimed to encourage the participants to identify the parenting style they adopt and alternatives for action, test changes in behavior between group meetings and evaluate the results of their efforts. The qualitative field research described corresponds to one of the groups created in 2018 in the context of an action research implemented at the University of Amazônia (UNAMA), Belém, located in Northern Brazil. We selected five participants who were present in at least $60 \%$ of the ten weekly meetings held in a group of mothers formed at the UNAMA psychology school clinic. Verbal exchanges in meetings and individual interviews supported the realization of content analysis, based on the formation of analysis categories corresponding to three parenting styles: authoritative or democratic, authoritarian and permissive. We noticed a growing movement of the participants towards the adoption of assertive and empathetic attitudes, combining display of affection with the establishment of consistent rules and limits. We conclude that changes towards the adoption of an authoritative parenting style generated positive impacts on family relationships based on the understanding of the role of model identified by the participants in themselves. Social skills made a difference in the family and led to developments in the behavior of children at school, indicating that it is a way to overcome the situation of social vulnerability in which they find themselves.
\end{abstract}

Keywords: Social vulnerability, parenting styles, social skills, group interventions.

\section{Introduction}

Social vulnerability situations have specific features depending on the social contexts evaluated. Thus, the inequality of opportunity between different sectors of the population is not limited to the so-called Global-South. According to Fischer and Fröhlich-Gildhoff (2019), even in the case of Germany, a country that represents the Global North or the West very well, foreigners and their descendants are considered socially vulnerable, being the focus of different interventions since joining in preschool.

Childhood is usually seen as a fundamental period for a given individual development. Longitudinal studies started in the 1950s on Kauai, an island in Hawaii, explain the importance of protective factors for the healthy development of children. Even when exposed to risk factors since birth, the presence of a significant adult in childhood, supporting and trusting them, favors the development of resilience and the overcoming of different challenges throughout development (Werner \& Smith, 1982).

Protection and risk factors are still being studied in different contexts. In this work, we highlight those related to parenting styles, considering that the way parents act in order to educate their children can have predictable positive and negative effects, although not always by themselves.

Parental styles were differentiated taking into account two dimensions of disciplinary practices responsiveness to children's needs and parental demand. One of the styles is considered the most appropriate, as it represents the presence of the two dimensions (authoritative style). In the others, therefore, there is the absence of both (negligent style) or the most striking presence of one of them, such as responsiveness (indulgent style) or demand (authoritarian style) (Weber, Prado, Viezzer, \& Brandenburg, 2004). It is worth noting that Baumrind (1966) previously categorized only three parenting styles. Indulgent and negligent styles are a development of what he identified as permissive style. 
On the other hand, aggressiveness, passivity and assertiveness are broad classes of interpersonal performances (Del Prette \& Del Prette, 2011) that allow the establishment of the following statements: authoritative parents would be more assertive, while authoritarian parents would tend to be more imposing and even aggressive, and indulgent and negligent parents would be closer to passivity in the face of their children's wishes and demands.

There is a vast literature that highlights the value of assertiveness for the quality of interpersonal relationships and even for the quality of life. The assertive individual would be better able to express his thoughts and feelings, respectfully sharing his internal world. Being assertive also involves gathering words and acting consistently with them, favoring an alliance between understanding and being understood. According to Teixeira, Del Prette and Del Prette (2016), one of the most used concepts of assertiveness defines it as an "ability to express feelings and desires appropriately, defend one's own rights and respect those of the other" (p. 57).

Considering that the authoritative parenting style favors relationships between parents and children (Weber et al., 2004), children who live with parents adopting it have assertiveness models at home since the beginning of life. Closing the argument, the positive exchanges would favor social skills, the support, and the confidence necessary for the development of resilience.

Resilience is a term that can be opposed to vulnerability (Fischer \& Fröhlich-Gildhoff (2019), but social vulnerability implies disadvantages that are widely distributed to a certain segment of the population. Such people are exposed to the maintenance of the underprivileged situation in which they find themselves at the present moment and beyond, in the case of their descendants (Wünsche \& Fischer, 2020). Although strengthening individuals is not enough to reverse generalized social injustices, it is easy to see the double destructive effect of the encounter between social vulnerability and emotional fragility, especially in the family environment, where the protection of children's healthy development is expected.

With this field study we describe procedures that are being investigated and refined in an action research that combines non-coercion, social skills and resilience. We present group interventions with mothers in situation of social vulnerability, aiming to encourage the participants to identify the parenting style they adopt and alternatives for action, test changes in behavior between group meetings and evaluate the results of their efforts. In the action research the procedures used are evaluated and improved in order to allow future advances.

\section{Experiential groups}

This qualitative field study corresponds to one of the groups created in 2018 in the context of an action research implemented at the University of the Amazon (UNAMA), in Belém, in the north of Brazil, entitled "Experiential Groups and Life in Society: An Interdisciplinary Intervention" (Darwich \& Garcia, 2019).

Five participants from a group of mothers formed at UNAMA's school-clinic of psychology (CLIPSI) participated in the study. The children's ages ranged from 6 to 12 years; the mothers', between 20 and 40 years. The inclusion criterion was an attendance of least $60 \%$ in the ten weekly meetings held.

The conversation circle started at each meeting with the shared reading of a poem, followed by reflections on themes brought up by the participants, for instance: general information on the positive effects of assertiveness and coping with problems through dialogue; negative effects of punishments, escapes and avoidances; relationships between actions, thoughts and feelings; and how to favor self-esteem and self-confidence (Del Prette \& Del Prette, 2017; Guilhardi, 2002; Sidman, 1989, Skinner, 1965). Reading poems together turned out to be a form of greeting from which a first question was derived, initiating the exchange of impressions and information.

Using the content analysis methodology (Bardin, 2011), three categories of analysis were created, corresponding to the authoritarian, permissive and authoritative parenting styles. For the purpose of analyzing results, we consider that such styles represent, respectively, the adoption of mainly aggressive, passive and assertive attitudes in disciplinary practices.

When the meetings started, four out of the five participants described attitudes typical of the authoritarian parenting style, with several examples of adopting an aggressive posture and difficulty regarding responsiveness, in the sense of also pointing out situations in which they showed little empathy towards their children's demands. One of the participants, on the contrary, adopted the permissive parenting style, being frequently passive towards child's demands. Therefore, none of the participants adopted the authoritative style. 
After the ten meetings, one of the participants, initially authoritarian, reported to adopt the authoritative style. Another participant, although she started to give examples of less aggressive and more assertive exchanges with her son, still shouted at him when being disobeyed. The other participants, two of which with previously aggressive posture and one with passive posture, started to talk more with the children, reproducing the dialogue and the assertive reflections characteristic of the group's meetings.

It is important to note that in all five cases there was more dialogue and flexibility, less shouting, more attention, greater affection and a greater focus on the child, accompanied by praise. We concluded that only one participant managed to change towards the adoption of the authoritative style because in her case there was a clear balance between the assertive presentation of rules and limits through active listening to the child and flexibility (when necessary). In other cases, rules and limits continued to be imposed in a less flexible or less consistent manner, although the positions adopted have become more affectionate and all participants have reported important advances in the family relationship quality.

\section{Conclusions}

With the exchanges established in the meetings and the gradual construction of greater self-knowledge and sensitivity in the face of different perspectives, changes towards the adoption of an authoritative parenting style were observed to varying degrees among the participants. If adults are role models for children, they are also for other adults. Thus, the experiential group became a place of speech and care; being part of it meant an opportunity to listen and be heard, to agree and disagree, and to receive the necessary support to apply the knowledge acquired in the family's daily life.

It is important to highlight the "domino effect" of the changes we have made. Assertiveness and empathy in the family environment generated positive impacts on the children's school life. The new attitudes of mothers also tend to favor children to develop resilience. Together, we can foresee the favoring of personal resources construction, with inevitable and necessary social consequences in the fight to overcome the situation of social vulnerability that a large portion of the population of Brazil finds itself.

\section{References}

Bardin, L. (2011). Análise de conteúdo. São Paulo: Edições 70.

Baumrind, D. (1966). Effects of authoritative control on child behavior. Child Development, 37, 887-907.

Darwich, R. A., \& Garcia, M. L. G. (2019). Grupos vivenciais e permanência com sucesso na escola: conquista de direitos. Revista Katálysis, 22 (3), 558-565.

Del Prette, A., \& Del Prette, Z. A. P. (2011). Enfoques e modelos do treinamento de habilidades sociais. In A. Del Prette, \& Z. A. P. Del Prette (Eds.). Habilidades sociais: Intervenções efetivas em grupo (19-56). São Paulo: Casa do Psicólogo.

Del Prette, A., \& Del Prette, Z. A. P. (2017). Competência social e habilidades sociais: manual teórico-prático. São Carlos: EDUFSCar.

Fischer, S., \& Fröhlich-Gildhoff, K. (2019). Chancen-gleich. Kulturelle Vielfalt als Ressource in frühkindlichen Bildungsprozessen. Manual zur Qualifizierung pädagogischer Fachkräfte. Stuttgart, Germany: Kohlhammer.

Guilhardi, H. J. (2002). Autoestima, autoconfiança e responsabilidade. In, M. Z. S. Brandão, F. C. S. Conte, \& S. M. B. Mezzaroba (Eds.), Comportamento humano: tudo (ou quase tudo) que você precisa saber para viver melhor (63-98). Santo André, SP: ESETec.

Sidman, M. (1989). Coercion and its fallout. Boston, MA: Authors Cooperative.

Skinner, B. F. (1965). Science and human behavior. New York: Free Press.

Teixeira, C., Del Prette, A., \& Del Prette, Z.A. P. (2016). Assertividade: uma análise da produção acadêmica nacional. Revista Brasileira de Terapia Comportamental e Cognitiva, 18 (2), 56-72.

Weber, L. N. D., Prado, P. M., Viezzer, A. P., \& Brandenburg, O. J. (2004). Identificação de estilos parentais: O ponto de vista dos pais e dos filhos. Psicologia: Reflexão e Crítica, 17 (3), 323-331.

Werner E., \& Smith, R. (1982). Vulnerable but invincible: A study of resilient children. New York: McGraw-Hill.

Wünsche, M., \& Fischer, S. (2020). Community Resilience. Networks for Developing Successful Migration. M. Fingerle, \& R. Wink (Eds.). Forced Migration and Resilience. Conceptual Issues and Empirical Results (45-70). Wiesbaden, Germany: Springer. 